\section{Jandarma Teşkilatı'nın 15 Temmuz 2016 Darbe Girişimi Sonrası Dönüşümü ${ }^{1}$}

\section{Transformation of the Gendarmerie after the Coup Attempt on 15 July 2016}

\author{
Abdullah ÖZÜBEK ${ }^{2}$ \\ Sezai ÖZTOP ${ }^{3}$
}

Journal of Civilization Studies Volume 6, Issue 2, pp.19-30 December 2021

DOI: $10.52539 / \mathrm{mad} .1038286$ Received: 20.12.2021 Accepted: 31.12.2021 (C) The Author(s) 2021

For reprints and permissions: https://dergipark.org.tr/tr/pub/mad

\title{
$\ddot{O} z$
}

Türk idari ve adli kolluk teşkilatlanmasının önemli yapıtaşlarından olan Jandarma teşkilatının görev ve yetkileri ilk kez 1930 yılında 1706 sayıl Jandarma Kanunu ile düzenlenmiștir. Müteakip düzenleme 1983 tarihli 2803 sayll Jandarma Teşkilat, Görev ve Yetkileri Kanunu'dur. Kanun'a göre Jandarma teşkilatı, bir kolluk kuvveti olarak emniyet ve asayişi sağlamaya yönelik mülki görevleri, suçluların yakalanması ve yetkili merciler önüne çıkarılmasına ilişkin adli görevleri, Türk Silahlı Kuvvetlerinin bir parçası olarak askeri görevleri ve genel mevzuat ile kendisine verilen diğer görevleri yerine getiren çok fonksiyonlu bir teşkilattır.

15 Temmuz 2016 tarihinde FETÖ/PDY tarafindan gerçekleştirilen darbe girişiminin bastırllmasının hemen ardından 21 Temmuz 2016 tarihinde Cumhurbaşkanı başkanlığında toplanan Bakanlar Kurulu tarafindan Olağanüstü Hal ilan edilmiş, birçok alanda yasal ve yönetsel düzenlemeler ve değişiklikler yapılmıştır. Bu kapsamda değişiklikler yapılarak yeniden yapılandırılan kurumlardan birisi de Jandarma Genel Komutanlı̆̆ıdır. Jandarma Genel Komutanlı̆̆ askeri kolluk yapısindan genel kolluk yapısina dönüstürülmüștür. Yapılan düzenlemelerle Jandarma teșkilatı sivil otoriteye bağlı bir iç güvenlik kurumu haline getirilmiş, kamu düzeni ve güvenliğine karşı daha etkili mücadele edebilecek genel bir kolluk kuvvetine dönüşürrülmüş̧ür. Bu çalışmanın amacı, Jandarma teşkilatının tarihi geliş̧imi, yapısı ve işleyişsini inceleyerek 15 Temmuz sonrası ilan edilen Olağanüstü Hal (OHAL) döneminde çıkartılan Kanun Hükmünde Kararnameler (KHK) ile Jandarma teşkilatının yapısında gerçekleştirilen değişiklikleri, gerekçelerini, getirdiği yenilikleri ve Jandarma teşkilatına etkilerini açıklamaktır.

Sonuç olarak, gerçekleştirilen değişimlerin, Jandarma teşkilatının ihtiyaç halinde sivil otorite kontrolünde daha hızlı reaksiyon gösterebilmesine ve genel kolluk teşkilatının güçlenmesine yol açtığ değerlendirilmektedir.

Anahtar Kelimeler: Jandarma, İ̧̧ Güvenlik, Kolluk Teşkilatı.

\section{Abstract}

Mission and power of the gendarmerie, as one of the important cornerstones in Turkey, were regulated firstly by means of the law 1706 in 1930, as one of the important branches of law enforcement. Later in 1983, the law 2803 has been enacted on the organization, mission, and powers of the gendarmerie. According to the law, the Gendarmerie was defined as a multi-functional agency which executes some law-

\footnotetext{
1 Bu çalışma, sorumlu yazarın Burdur Mehmet Akif Ersoy Üniversitesi Sosyal Bilimler Enstitüsü, Siyaset Bilimi ve Kamu Yönetimi Programında 2019 yılında tamamlanan yüksek lisans projesinden üretilmiş ve İnönü Üniversitesi'nde düzenlenen 20. Kamu Yönetimi Forumu'nda (KAYFOR 20) özet bildiri olarak sunulmuştur.

2 İçişleri Bakanlığı, Bingöl Valiliği, Vali Yardımcısı, abdullah.ozubek@icisleri.gov.tr, ORCID: 0000-0003-4297-4156

3 Doç. Dr., İstanbul Medeniyet Üniversitesi Siyasal Bilgiler Fakültesi Siyaset Bilimi ve Kamu Yönetimi Bölümü, sezai.oztop@medeniyet.edu.tr, ORCID: 0000-0003-2656-2776
} 
enforcement functions in addition to military missions and general duties as a part of Turkish Armed Forces.

After the coup attempt of Fethullah's Terrorist Organization was suppressed, there have been many legal and administrative regulations carried out in various fields following the declaration of the state of emergency on 21 July 2016 by the Board of Ministries presided by the President of the Republic. Then, the Gendarmerie was one of the agencies in which some important transformations have been carried out. This agency has been taken out of military structure and integrated into general law-enforcement structure. By means of these regulations, gendarmerie has been transformed into a law enforcement agency to fight against any treats to public order and safety.

Aim of this study is to explain the transformation of the gendarmerie after 15 July 2016 following its historical development, structure, and functions. The changes after the coup-attempt, the justifications of the changes, and their effects on the gendarmerie are also presented in the study.

As a conclusion, it has been evaluated that the changes have enabled the gendarmerie to be able to react faster under the authority of civil government in case of requirement, and these changes have strengthened the general law enforcement structure.

Key Words: Gendarmerie, Domestic Security, Law Enforcement Organization.

\section{GíRIS}

Güvenlik hizmeti devletin klasik görevlerinden birisidir. Güvenlik risk ve tehditleri, çok uzun zamandan beri devletler açısından öncelikli konular arasındadır (Avaner ve Erciyes, 2019: 2,3). Modern devletin kuruluşundan bu yana savunma ve güvenlik harcamaları önemli paya sahiptir. Ayrıca, asimetrik güç mücadeleleri devletlerin iç ve dış güvenlik teşkilatlarının daha yakın bir iletişim ve koordinasyon içinde çalışmasına yol açmıştır. Soğuk savaş döneminin askeri güvenliği önceleyen çift kutuplu dünyasına yönelik kurgulanan güvenlik anlayışı geçmişte kalmıştır (Avaner ve Şencan, 2019: 617). Gelişmelerin yol açtığı sonuçlardan birisi de güvenlik alanındaki kamusal örgütlerin kendi içinde hiyerarşik bir yapıdan ağ tipi örgütlenmeye doğru evrilmesi olmuştur. Örneğin ABD, 11 Eylül olayları sonrasında iç güvenlik kurumlarında "Homeland Security" adıyla yeni bir bakanlık teşkil etmiş ve federal/yerel düzeyde 22 kurum ve bu kurumların 180.000 çalışanını tek bir çatı altında toplamıştır (Avaner, Tek ve Özgür, 2019: 2).

Türkiye'de iç güvenlik meselesi en önemli konuların başında gelmektedir. Gerek bulunduğu coğrafya gerekse kültürel ve demografik yapısından dolayı büyük mücadeleler yaşanmaktadır (Avaner ve Şencan, 2019: 618). Türkiye'de iç güvenlik birimleri Emniyet Genel Müdürlügü, Jandarma Genel Komutanlığı ve Sahil Güvenlik Komutanlığı'dır.

$\mathrm{Bu}$ çalışmanın ilgi alanını oluşturan Jandarma Teşkilatı Osmanlı Devleti döneminde kurulmuştur. Görev ve yetkileri Cumhuriyet döneminde ilk kez 1930 yılında, 1706 sayılı Jandarma Kanunu ile düzenlenmiş ve 1983 yılında ise 2803 sayılı Jandarma Teşkilat, Görev ve Yetkileri Kanunu onun yerini almıştır. Kanun'da Jandarma teşkilatı, bir kolluk kuvveti olarak emniyet ve asayişi sağlamaya yönelik mülki görevleri, suçluların yakalanması ve yetkili merciler önüne çıkarılmasına ilişkin adli görevleri, Türk Silahlı Kuvvetlerinin bir parçası olarak askeri görevleri ve genel mevzuat ile kendisine verilen diğer görevleri yerine getiren bir kurum olarak tanımlanmaktadır.

15 Temmuz 2016 tarihinde FETÖ/PDY tarafından gerçekleştirilen darbe girişiminin bastırılmasının ardından 21 Temmuz 2016 tarihinde Cumhurbaşkanı başkanlığındaki Bakanlar Kurulu Olağanüstü Hal (OHAL) ilan etmiştir. OHAL dönemi içinde OHAL KHK'ları ile sivil otorite tarafından darbe girişimine zemin hazırladı̆̆ değerlendirilen alanlarda çeşitli idari düzenlemeler yapılmış ve değişikliklere gidilmiştir. Değişiklik yapılan kurumlardan birisi de Jandarma Genel Komutanlığı olmuştur. Yapılan düzenlemelerle Jandarma teşkilatının, Genelkurmay Başkanlığı ile hiyerarşik bağı kaldırılarak doğrudan sivil otoriteye bağlı bir iç güvenlik kurumu haline getirilmesi, kamu düzeni ve güvenliğine yönelik tehditlere karşı daha etkili şekilde mücadele edebilecek, genel bir kolluk kuvvetine dönüştürülmesi amaçlanmıştır.

$\mathrm{Bu}$ çalışmanın amacı, Jandarma teşkilatının tarihi gelişimi, yapısı ve işleyişini inceleyerek 15 Temmuz sonrası ilan edilen Olağanüstü Hal döneminde çıartılan OHAL KHK'ları ile Jandarma 
teşkilatının yapısında gerçekleştirilen değişiklikleri, bu değişikliklerin gerekçelerini, getirdiği yenilikleri ve Jandarma teşkilatına etkilerini açıklamakla sınırlıdır. Çalışmanın ilk bölümünde, kolluğa ilişkin temel kavramlar ve Türk Jandarma teşkilatının tarihçesi, ikinci bölümde, 15 Temmuz öncesi Jandarma teşkilatının idari yapısı ve işleyişi, üçüncü bölümde ise 15 Temmuz sonrası ilan edilen OHAL KHK'ları ile Jandarmanın idari yapısında gerçekleştirilen değişiklikler incelenmektedir.

\section{KAVRAMLAR VE TARIHSEL GELISSIM} alınmaktadır.

$\mathrm{Bu}$ bölümde, kolluk ve jandarma kavramları ile jandarma teşkilatının tarihsel gelişimi ele

\subsection{Kolluk}

İdarenin kamu düzenini sağlama, koruma ve bu düzenin bozulması halinde eski hale getirme için bireysel ve toplumsal davranışları düzenlemesi ve toplum düzenine aykırı eylemleri kuvvet kullanarak önlemesi amaciyla oluşturduğu teşkilata, yürüttüğü faaliyete ve bu faaliyeti yerine getiren personele "kolluk" adı verilmektedir. Kolluk sadece bir faaliyeti değil, bu faaliyeti yerine getirmek için oluşturulan teşkilatı ve bu faaliyeti yerine getiren personeli de içeren geniş bir kavramdır. Literatür ve mevzuattan anlaşılacağı üzere kolluğun amacı, kamu düzeninin korunması ve bozulan kamu düzeninin sağlanmasıdır. Bu bağlamda kamu düzenini oluşturan unsurlar güvenlik, dirlik ve esenlik, genel sağlık ve genel ahlâk olarak siralanmaktadır (Akyılmaz vd., 2016: 585, 586).

Kolluk, "idari kolluk" ve "adli kolluk" olarak ikiye ayrılmaktadır. İdari kolluk, kamu düzeninin bozulmaması için alınan tedbirleri ifade ederken, adli kolluk ise düzenin bozulmasını müteakip suç faillerini ve delilleri araştırıp bularak adli makamlara teslim etmek suretiyle düzeni yeniden sağlamayı amaçlamaktadır. Türkiye'de idari ve adli kolluk işlevsel olarak ayrı olsa da organik bir ayrım görülememektedir. (Avaner ve Erciyes, 2019: 8, 9).

İdari kolluk, belirli idari otoriteler tarafından kullanılan ve kamu düzenini sağlamak amacıyla kişi hürriyetlerine sınırlama ve yasaklar koyan bir müdahale şeklidir (Güner, 2011: 8). İdari kolluk faaliyetinin en önemli özelliği kamu düzeninin bozulmasını önleyici ve koruyucu nitelikte olmasıdır. Bu özellik idari kolluğu, adli kolluktan ayıran temel farktır. Dolayısıyla idari kolluğun amacının kamunun düzen içinde yaşamasını sağlamak olduğu ifade edilebilir.

İdari kolluk faaliyetleri, genel idari kolluk ve özel idari kolluk olmak üzere ikiye ayrılmaktadır. 3201 sayılı Emniyet Teşkilatı Kanunu, zabıta (kolluk) teşkilatını umumi ve hususi olarak ayırmakta; genel kolluk olarak polis ve jandarma sayılmaktadır. Ancak bu kanun maddesinde yer almasa da son yıllarda yapılan mevzuat değişiklikleri göz önünde bulundurulduğunda Türkiye'de kıyı emniyeti ve karasuları güvenliğinden sorumlu olan Sahil Güvenlik Komutanlığı da genel kolluk kuvveti olarak görülebilir.

Özel kolluk ise genel kolluk dışında özel kanunlara göre kurulan ve bu kanunla verilen görevleri yapan kolluktur. 1982 Anayasası'nın 123. maddesine göre "İdare, kuruluş ve görevleriyle bir bütündür ve kanunla düzenlenir. İdarenin kuruluş ve görevleri, merkezden yönetim ve yerinden yönetim esaslarına dayanır."

Genel idari kolluk, kamu güvenliği, kamu huzuru ve genel sağlık amaciyla belirli bir coğrafya üzerinde bulunan her birey, her grup ve her çeşit faaliyet hakkında yetkili olan kolluktur (Gözler ve Kaplan, 2018: 288). Dolayısıyla Türkiye'de genel idare kolluk, merkezi idare kolluğu ve mahalli idareler kolluğu olarak ikiye ayrılabilir (Gözler ve Kaplan, 2011: 473). 1982 Anayasası'nın 127. maddesinde Mahalli İdareler, il, belediye ve köy idaresi olarak düzenlendiğinden dolayı mahalli kolluklar il özel idaresi kolluğu, belediye kolluğu ve köy kolluğundan oluşmaktadır. İdari kolluk faaliyeti yürüten tüm birimler devletin yürütme erkini temsil eden makamların emri altında görev yapmaktadır. Bu bağlamda genel idari kolluk makamları Cumhurbaşkanı, İçişleri Bakanı ve mülki idare amirleri olarak vali ve kaymakamdır.

Emniyet Teşkilatı Kanunu'ndaki tanıma ek olarak Jandarma Teşkilatı, Görev ve Yetkileri Yönetmeliği’nin 3. maddesinde özel idari kolluk; "Devlet ve yetkili diğer kamu tüzel kişilerince, özel kanunlar çerçevesinde kurulup teşkilatlandırllan; kendi görev alanında güvenliği sağlamak amacı taşıyan ve jandarma, sahil güvenlik ve polis dışındaki kolluk birimleri” şeklinde tanımlanmaktadır. Hizmet kolluğu olarak adlandırılan özel idari kolluğu, genel idari kolluktan ayıran en temel özellik, özel idare kolluğun 
kendi kolluk faaliyetlerini sadece belirli bir alanda ve konuda icra edebilmesidir (Orman Kolluğu, Maliye Kolluğu vb.).

\subsection{Jandarma}

"Jandarma" kelimesi, Fransızca "Gendarmerie" kelimesinden Türkçeye geçmiştir. Fransız kaynaklarında jandarma "gens" ve "d'armes" kelimelerinin birleşmesinden meydana gelmiş olup "silahlı adamlar" anlamına gelmektedir (Çermeli ve Atabey, 2002: 149). Jandarma kelimesinin, Mısır' da yaşayan Türkler tarafindan kullanılan Farsça kökenli "candar" sözcüğünden geldiğini belirten görüşler de bulunmaktadır. Bu görüşe göre candarma; hayat, sağlik anlamına gelen "can" ve tutan, tutucu anlamına gelen "dar" sözcüklerinin birleşmesinden meydana gelmiştir. Nitekim, Anadolu köylerinde jandarma "candarma" olarak telaffuz edildiği görülmektedir (Kahraman, 2000: 4).

Jandarmanın kuruluş tarihi ile ilgili olarak ortaya çıkan değişik görüşler, jandarmanın kuruluş gününün farklı tarihlerde kutlanmasına neden olmuştur. Önceleri, 1706 Sayılı Jandarma Kanunu'nun yayımlandığı tarih olan 22 Haziran 1930'un 22 Haziranı ile Asakir-i Zaptiye Nizamnamesinin yayımlandığ yıl olan 1869 birleştirilerek 22 Haziran 1869 tarihi, kuruluş günü kabul edilmiştir. Sonraları Zaptiye Müşirliği'nin kuruluş tarihi olan 16 Şubat 1846, jandarmanın kuruluş günü olarak kabul edilmeye başlanmıştır. Sonraki süreçte Tanzimat Fermanının ilan edildiği 1839 yılı ile Asakir-i Zaptiye Nizamnamesinin (Askeri Kolluk Tüzüğü) yürürlüğe girdiği 14 Haziran günü birleştirilerek, 1969 yılında yayımlanan bir emirle Jandarma Genel Komutanlığg'nın kuruluş tarihi 14 Haziran 1839 olarak kabul edilmiştir (Çermeli ve Atabey, 2002:150). ${ }^{1}$

\subsection{Tarihsel Gelişim}

Osmanlı Devleti idari yapısı itibarı ile eyaletlere, eyaletler sancaklara, sancaklarda kazalara bölünmüş olup eyaletlerde padişahı temsil eden beylerbeyi, sancaklarda sancak beyleri, kazalarda ise kadıların emrinde subaşılar askeri ve siyasi otorite olarak kolluk (zabıta) faaliyetlerini yürütmüşlerdir. Devletin merkezi olan İstanbul'da ise özel bir statü geçerliydi. İstanbul'da güvenliğin sağlanmasından yeniçeri ağası sorumlu olup cebeci başı, kaptan paşa, topçu başı ve bunlara bağlı teşkilatlar da zabita faaliyetleri ile görevliydi.

Osmanlı Devleti’nin kuruluşunu müteakip ordu, önceki dönemlerde olduğu gibi dışta düşmanlara karşı ülkeyi korumak, içte ise emniyet ve asayişi sağlamakla görevlendirilmiştir. Osman Bey 1301 y1lında Karacahisar'ı ele geçirdikten sonra bu şehrin idaresini oğlu Orhan Bey’e vermiş ve subaşı olarak Gündüz Alp'i atamıştır. Dolayısıyla ilk zabıta amiri olarak Gündüz Alp kabul edilmektedir (Çermeli ve Atabey, 2002: 94). Kolluk faaliyetlerinin askeri makamlar tarafından bu şekilde yürütülüşü 1826 yılına kadar devam etmiştir. 1826 yılına kadar Türklerde kolluk teşkilatı ve faaliyetinin genel niteliği; askeri makamların aynı zamanda kolluk makamı olduğu, belirli ve düzenli kolluk teşkilatının emir, ferman, örf ve âdete göre yürütülen bir faaliyet olduğu şeklindedir (Aktürk vd., 2004: 1). Yeniçeri Ocağı'nın kaldırıldığg 18 Haziran 1826 tarihinden Cumhuriyet dönemine kadar, Türk Jandarma Teşkilatının kuruluş ve gelişimi aşağıda sıralanan dönemlere ayrılmaktadır.

İlk Zaptiye Birlikleri dönemi, Yeniçeri Ocağının kaldırılmasından (1826) Zaptiye Müşirliği’nin kuruluşuna (16 Şubat 1846) kadar geçen süreyi kapsar. Osmanlı Devleti'nde düzenli orduyu teşkil eden Yeniçeri Ocağının bozulması, disiplini kaybetmesi üzerine 1826 yılında bu Ocak kaldırılmış ve Asakir-i Muntazama-i Mensure ve Asakir-i Muntazama-i Hassa kurulmuştur (Açıkmeşe, 1993: 312).

Osmanlı Devletinin zor ve çalkantılı bir dönemden geçişi yeni kurulan bu örgütlerin eyaletlerdeki kolluk faaliyetlerini yürütmede etkisiz kalmasına yol açmıştır. 1839 tarihli Gülhane Hattı Hümayunu ile kolluk faaliyeti ve örgütlenmesi açısından yeni bir süreç başlamıştır. Tanzimat Fermanı'nın en önemli amaçlarından biri halkın can, ırz, namus ve mal güvenliğini korumak olarak ilan edilmiştir. Bu şekilde kişilerin yaşam hakkı güvenlik altına alınmak istenmiştir. Ancak iç güvenlik teşkilatının, teşkilat ve görev yönünden 1slahı için büyük çabalar sarf edilmesine rağmen yine de teşkilatın tek elden bağımsız olarak sevk ve idaresi ile yasal bir mevzuata kavuşturulması sağlanamamıştır (Korkusuz, 1998: 205).

Kolluk teşkilâtları arasında emir komuta birliği 1846 yılında Zaptiye Müşirliği’nin kurulması ile

\footnotetext{
${ }^{1}$ Bkz. Jandarma Genel Komutanlığı Web Sitesi, https://www.jandarma.gov.tr/tarihce
} 
sağlanmıştır. Bu dönemde emniyet ve asayişin sağlanmasında görevli askerî birlikler, Zaptiye Müşirliğine bağlanarak ülke çapında düzenli bir kolluk teşkilâtı kurulmaya başlanmıştır. 14 Haziran 1869 tarihinde Asakir-i Zaptiye Nizamnamesi çıkarılarak Zaptiye Müşirliği yasal bir düzenleme altına alınmıştır. Bu nizamnameyle illerde zaptiye alayı kurulmuş, alayların altında tabur, bölük ve takımlar teşkil edilmiştir. Nizamnameyle bu teşkilata idari, adli, askeri ve belediye kolluğu görevleri de verilmiştir (Akman, 1991: 64). Bu dönem kolluk teşkilatının iç güvenlik ve kamu düzenini sağlama görevi bakımından tek elden sevk ve idare edildiği dönemdir. Ancak teşkilatın idari yapısındaki düzenlemelere ve yasal mevzuatın yürürlüğe konmasına rağmen gerek Osmanlı Devletinin içinde bulunduğu dönemin özelliği, gerekse teşkilata personel seçimi ve eğitimindeki hatalar bu düzenlemelerin başarısına mani olmuştur (İleri, 2004: 47).

1877-1878 Osmanl1-Rus Savaşı'ndan sonra orduda yapılan yenileştirme faaliyetleri kolluk teşkilatına da yansımıştır. Kolluk teşkilatında düzen ve disiplinin bozulması üzerine Sadrazam Sait Paşa kolluk teşkilatının yeniden düzenlenmesi için Fransa ve İngiltere'den subaylar getirmiştir. Avrupa' daki gibi güçlü bir jandarma teşkilatı kurulması amaçlanmıştır. Sadrazam Sait Paşa'nın 20.11.1879 tarihli emriyle yeni bir kolluk teşkilatının kurulması çalışmalarına başlanmış, yeni kurulacak teşkilatın ismi jandarma olarak belirlenmiştir. Kolluk faaliyetlerini 1846 yılından beri mülki makamların emri altında yerine getiren Zaptiye Müşirliği yeniden seraskerliğe bağlanmış, adı da Zaptiye Nezareti olarak değiştirilmiştir. Jandarma makamı da Umum Jandarma Merkeziyesi olarak kabul edilmiş̧ir (Açıkmeşe, 1993: 314).

1908 yılında II. Meşrutiyetin ilanını müteakip Fransa ve İngiltere'den getirilen yabancı subaylar Rumeli'de bazı illerde görevlendirilmiş, jandarma teşkilatı Fransız jandarması örnek alınarak teşkilatlandırılmıştır. 1903 yılında Fransız Jandarma Kanunu tercüme edilerek Jandarma Nizamnamesi çıkarılmıştır (Aktürk vd., 2004: 2).

1879-1909 yılları arasında özellikle II. Meşrutiyetin ilanından sonra yabancı subayların getirilmesi ile yeniden teşkilatlanan Jandarma Teşkilatının Rumeli'de gösterdiği başarılar üzerine Teşkilatın bütün ülke genelinde kurulup yaygınlaştırılmasına çalışılmıştır. Jandarma teşkilatı Harbiye Nezaretine bağlı kalmış ancak Umum Jandarma Komutanlığı adı altında teşkilatlanmıştır (Açıkmeşe, 1993: 315). Bu dönemde Jandarma Teşkilatına yasal kimlik sağlamak amacıyla Jandarma Kanunu yürürlüğe girmiş, 26 Ekim 1917 tarihinde ise jandarmanın mülki makamlarla ilişkisine yönelik bir kararname çıkarılmıştır. Jandarma, 16 Mart 1919 tarihinde Damat Ferit Paşa hükümeti tarafından İçişleri Bakanlığına bağlanmıştır (Aktürk vd., 2004: 3).

Ankara'da Büyük Millet Meclisi’nin açılmasından sonra teşkil edilen Meclis Hükümeti, bir taraftan düzenli ordunun kuruluşu için çalışırken, bir taraftan da iç güvenliği temin için uğraşıyordu. İç güvenlik amacıyla Milli Savunma Bakanlığı'na bağlı olarak Umum Jandarma Kumandanlığı kuruldu. Jandarma Umum Komutanlığı, TSK'nın bir organı olarak sekiz bölge müfettişliği ile bunlara bağlı 17 jandarma alayı ve 13 bağımsız jandarma taburundan oluşuyordu (Efe, 2016: 594-595).

Cumhuriyetin ilanıyla birlikte devlet kuruluşlarında köklü bir değişiklik ve yapılanma çalışması başlamıştır. Jandarma Teşkilatı ile ilgili olarak da önemli mevzuat değişiklikleri gerçekleştirilmiştir. 1930 y1lında jandarmanın görev ve sorumluluklarını, hukuki statüsünü belirleyen 1706 sayılı Jandarma Kanunu kabul edilmiştir. $\mathrm{Bu}$ kanuni düzenleme ile bugünkü Jandarma Teşkilatının teşkilat yapısı kurulmuştur (Akman, 1991: 66). Bu dönemde jandarmanın bağlılı̆̆ı konusunda üç parçalı bir düzenleme yapılmış, 1930 yılında çıkarılan 1706 Sayılı Jandarma Kanunu ve 1937 yılında çıkarılan Jandarma Teşkilât ve Vazife Tüzüğü ile jandarma (JOK, 2004: 1-11):

(1) Emniyet ve asayiş ile ilgili görevleri bakımından İçişleri Bakanlığına,

(2) Eğitim ve öğretim yönünden Genelkurmay Başkanlığına,

(3) Silâh ve mühimmat temini, seferde Kara Kuvvetlerine katılacak personel ile kıyafet ve teçhizatları yönünden Milli Savunma Bakanlığına bağlanmıştır.

1935 yılında Jandarma subaylarının Kara Harp Okulu'nda yetiştirilmesi esası kabul edilmiş; "Jandarma Umum Komutanlığı” ismi "Jandarma Genel Komutanlığı”na dönüştürülmüştür. Bu dönemde Jandarma Genel Komutanın rütbesi “Korgeneral”dir (Çermeli ve Atabey, 2002: 209).

1939 yılında sabit jandarma birlikleri, seyyar jandarma birlikleri, jandarma eğitim birlikleri ve okullar kurulmuştur. 1956 yılında yürürlüğe giren 6815 sayılı kanunla Gümrük ve Tekel Bakanlığına bağlı 
Gümrük Umum Müdürlüğü kaldırılarak sınırların emniyet ve korunması ile kaçakçılığın men, tahkik, talep görev ve sorumluluğu İçişleri Bakanlığına verilmiş olup, bu görev Jandarma Genel Komutanlığı aracılığıyla yerine getirilmektedir (Akman, 1991: 67).

Organize suç ve suçlularla mücadele için ilk aşamada Jandarma Komando Birlikleri ve Havacılık Birlikleri kurularak emniyet ve asayiş görevinin etkili bir biçimde ifa edilmesi amaçlanmıştır. 1969 yılında da Jandarma Genel Komutanlığı bünyesinde Narkotik şube kurulmuştur (Açıkmeşe, 1993: 323).

1982 y1lında, 6815 sayılı kanun ile 1956 y1lında jandarmaya verilen sınır, kıyı ve karasularının korunması ve güvenliğinin sağlanması görevlerinden kıyı ve karasularını koruma görevi, 2692 sayılı Kanunla Sahil Güvenlik Komutanlığına, kara sınırlarının korunması ve güvenliğinin sağlanması görevi ise 1988 yılında 3497 sayılı kanunla Kara Kuvveleri Komutanlığına verilmiştir (Çermeli ve Atabey, 2002: 213). 10 Mart 1983 tarihinde 1706 sayılı Jandarma Kanunu kaldırılarak halen 2803 sayılı Jandarma Teşkilat, Görev ve Yetkileri Kanunu kabul edilmiştir.

\section{15 TEMMUZ ÖNCESİ JANDARMA TEŞKİLATI}

Bu bölüm, jandarma teşkilatının 15 Temmuz 2016 öncesi durumunu incelemek ve sonraki bölümde 15 Temmuz sonrası düzenlemelerle karşılaştırma yapabilmek amacıyla tanım, bağlılık, kuruluş ve teşkilat, görevler, personel kaynağı ve özlük hakları, atanma, disiplin ve soruşturma ile ikmal esasları şeklinde sekiz alt başlık olarak düzenlenmiştir.

\subsection{Tanım}

1983 tarihli 2803 sayılı Jandarma Teşkilat, Görev ve Yetkileri Kanunu'nun (JTGYK) 3. maddesinde Jandarma, emniyet ve asayiş ile kamu düzeninin korunmasını sağlayan ve diğer kanun ve nizamların verdiği görevleri yerine getiren silahlı, askeri bir güvenlik ve kolluk kuvveti olarak tanımlanmıştır. Jandarmanın silahlı bir kolluk kuvveti olmasının yanı sıra "askeri" bir güvenlik kuvveti olarak tanımlandığı görülmektedir.

\subsection{Bağlılık}

Jandarma teşkilatının bağlılığını düzenleyen 2803 Sayılı JTGYK'nın 4. maddesine göre Jandarma teşkilatı, hiyerarşik olarak iki farklı kuruma bağlıdır. Birincisi, Türk Silahlı Kuvvetlerinin bir parçası olarak silahlı kuvvetlerle ilgili görevleri ile eğitim ve öğrenim bakımından Genelkurmay Başkanlığına, İkincisi ise emniyet ve asayiş işleri ile diğer görev ve hizmetlerin ifası yönünden İçişleri Bakanlığına bağlıdır.

\subsection{Kuruluş ve Teşkilat}

2803 Sayılı JTGYK'nın 5. Maddesine göre, Jandarma Genel Komutanlığının kuruluş ve kadrolarıyla konuş (görev) yerleri, olağan dönemlerde Genelkurmay Başkanlığının görüşü alınarak İçişleri Bakanlığı tarafından düzenlenirken, seferberlik ya da savaş durumlarında Kuvvet Komutanlıkları emrinde, Genelkurmay Başkanlığı onayı ile gerçekleşir. Bu bağlamda Jandarma teşkilatının kuruluş ve kadrolarıyla görev yerlerinin tespitinde esas yetkinin Genelkurmay Başkanlığına yani askeri otoriteye ait olduğu ayrıca bu hususların TSK'nın askeri yapısı ve görevleri dikkate alınmak suretiyle düzenleneceği anlaşılmaktadır.

\subsection{Görevler}

Jandarmanın sorumluluk alanlarında genel olarak görevleri 2803 Sayılı JTGYK'nın 7. Maddesinde; mülki, adli, askeri ve diğer görevler olarak sıralanabilir. Mülki görevler; suç işlenmesini önlemek, kamu düzeni ve güvenliğini korumaya ilişkin idari (önleyici) kolluk görevleridir. Ceza İnfaz Kurumlarının dış güvenliğini sağlamakta Jandarmanın mülki görevleri arasında sayılmaktadır. Adli görevler; kamu düzeni ve güvenliğinin ihlal edilmesi ve suç işlenmesi durumunda adli hizmetlerin yerine getirilmesine ilişkin kolluk görevleridir. Askeri görevler; Genelkurmay Başkanlığı ile askeri mevzuatın Jandarma teşkilatına verdiği görevlerdir. Bu görevlerin yanı sıra ihtiyaç duyulması halinde seferberlik ve savaş durumunda Genelkurmay Başkanlığı kararı ile Jandarma teşkilatının bir bölümü Kuvvet Komutanlıkları emrine girmektedir.

\subsection{Personel Kaynağı ve Özlük Hakları}

Jandarma teşkilatının personel, kaynakları ve buna ilişkin uygulanacak mevzuatı düzenleyen 2803 Sayılı JTGYK'nın 13. maddesi incelendiğinde; Jandarma teşkilatının subay, astsubay, uzman jandarma, 
askeri öğrenci, erbaş ve erler ile sivil memur ve işçilerden oluştuğu, subay ve astsubayların kaynak, yetiştirilme ve her türlü özlük işlemlerinin 926 sayılı Türk Silahlı Kuvvetleri Personel Kanunu'na göre yapıldığı görülmektedir. Bu personelin 657 sayılı Devlet Memurları Kanunu'na (DMK) tabi olmadığı, bu nedenle bir "Devlet Memuru" olarak değil "Diğer Kamu Görevlisi" olarak kamu hizmetini yerine getirdikleri anlaşılmaktadır. Jandarma personelinin sınıflara ayrılmasında asli yetkinin Genelkurmay Başkanlığına yani askeri makamlara ait olduğu, aynı şekilde Uzman Jandarma personelinin özlük işlemlerinin de 657 sayılı kanun dışında 635 sayılı Uzman Jandarma Kanunu hükümlerine göre yürütüldüğü, genel itibariyle Jandarma teşkilatında görevli rütbeli personelin kaynak, yetiştirilme ve özlük işlemlerinin düzenlenmesi açısından sivil otoritenin doğrudan bir yetkisinin bulunmadığı görülmektedir.

\subsection{Atama}

Jandarma personelinin atanma esaslarına ilişkin 2803 Sayılı JTGYK'nın 14. Maddesine göre;

a) Asteğmen, albay rütbeleri arasındaki subaylar ile astsubay ve uzman jandarmaların atanmaları Jandarma Genel Komutanı tarafindan,

b) Generallerin atanmaları; Jandarma Genel Komutanının lüzum göstermesi, Genelkurmay Başkanının teklifi, İçişleri Bakanının inhası, Başbakanın imzalayacağı ve Cumhurbaşkanın onaylayacağı müşterek kararnameyle,

c) Jandarma Genel Komutanının atanması Genelkurmay Başkanının teklifi, İçişleri Bakanının inhası, Başbakanın imzalayacağı ve Cumhurbaşkanının onaylayacağı müşterek kararnameyle yapilmaktadır.

Jandarma Genel Komutanlığ bünyesinde görev yapan general rütbesine kadar olan personelin doğrudan Jandarma Genel Komutanı tarafından atandığı, bunun dışında gerek generallerin gerekse Jandarma Genel Komutanın atanmasının Genelkurmay Başkanının teklifi üzerine müşterek kararname ile yapıldığ 1 , bu görevlere atanacak personelin tespiti aşamasında sivil makamların bir yetkisinin olmadığ 1 görülmektedir.

\subsection{Disiplin ve Soruşturma İşlemleri}

Jandarma personeli hakkında uygulanacak disiplin ve soruş̧urma işlemlerini belirleyen 2803 Sayılı JTGYK'nın 15. maddesine göre, Jandarma personeli hakkında uygulanacak disiplin cezalarında asli yetkinin askeri hiyerarşi içerisinde kendi disiplin amirine ait olduğu, mülki (idari kolluk) görevlerin ifası bakımından disiplin cezasını gerektiren durumlarda Jandarma personelinin görev yaptıkları yerlerde en üst kolluk amiri olan Mülki Amirlerin (vali/kaymakam) ilgili personel hakkında doğrudan idari bir işlem tesis etme yetkisinin bulunmadığı, bu konuda alay ya da bölük komutanlarına bir emir veya talimat veremeyip sadece disiplin cezası verilmesini talep edebildikleri, bu konuda mülki amirden bağımsız olarak askeri mevzuat çerçevesinde asli yetkinin ilgili alay ya da bölük komutanında olduğu görülmektedir.

\section{8. İkmal Esasları}

2803 Sayılı JTGYK'nın 19. maddesinde, Jandarma teşkilatının ikmal hizmetleriyle, faaliyetlerine ilişkin her türlü ihtiyaçlarının Türk Silahlı Kuvvetleri standartlarına uygun olarak kendi bütçesinden karşılanacağı ayrıca silah ve mühimmat ihtiyacının ise Milli Savunma Bakanlığı tarafından temin edileceği ifade edilmiştir.

\section{15 TEMMUZ 2016 SONRASI JANDARMA TEŞKİLATI}

\subsection{Tanım}

25/07/2016 tarih ve 668 sayılı KHK ile Jandarma teşkilatında yapılan ilk değişiklik Jandarmanın tanımını yapan 2803 Sayılı JTGYK'nın 3. maddesinde yapılmış olup yeni tanımla Türkiye Cumhuriyeti Jandarması, emniyet ve asayiş ile kamu düzeninin korunmasını sağlayan ve diğer kanunların ve Cumhurbaşkanlığı kararnamelerinin verdiği görevleri yerine getiren silahlı genel kolluk kuvveti olarak belirtilmiştir.

Türkiye Cumhuriyeti Jandarmasının, sadece bir kolluk kuvveti olarak kabul edildiği, dolayısıyla askeri güvenlik kuvveti olma vasfının kalktığı anlaşılmaktadır. Bu değişiklikle Jandarma teşkilatının askeri 
kimliğinden sıyrılarak doğrudan sivil otoriteye bağlı bir kolluk teşkilatı olması amaçlanmıştır.

Jandarma teşkilatının Cumhurbaşkanlığı Hükümet Sistemi ile uyumunu sağlamak amaciyla 09/07/2018 tarih ve 703 sayılı KHK ile bir değişiklik daha yapılmış ve "Cumhurbaşkanlığı kararnamelerinin" verdiği görevleri de yerine getirme misyonu yüklenmiştir.

\subsection{Bağlılık}

25/07/2016 tarih ve 668 sayılı KHK ile Jandarma teşkilatında yapılan ikinci değişiklik Jandarma teşkilatının bağll1ık durumunu düzenleyen 2803 Sayılı JTGYK'nın 4. maddesinde olmuştur. Eski düzenlemede Jandarma teşkilatı hiyerarşik olarak iki farklı kuruma bağlı idi. Yeni düzenleme ile Jandarmanın Genelkurmay Başkanlığına bağlılığı kaldırılmış, Türk Silahlı Kuvvetlerinin bir parçası olması uygulamasına son verilerek doğrudan İçişleri Bakanlığına bağlı genel bir kolluk teşkilatı haline gelmiş, dolayısıyla Bakanlığa bağlı diğer kolluk teşkilatları ile aynı statüye alınmıştır (Avaner, Tek ve Özgür, 2019: 16). Jandarmanın askeri hiyerarşi ile olan bağı kesilmek suretiyle Jandarma Genel Komutanının Milli Güvenlik Kurulu (MGK) ve Yüksek Askeri Şura (YAŞ) üyeliği görevleri de sona ermiştir.

\subsection{Kuruluş ve Teşkilat}

25/07/2016 tarih ve 668 sayılı KHK ile Jandarma teşkilatında yapılan diğer bir değişiklik Jandarma kuruluş ve teşkilat yapısını düzenleyen 2803 Sayılı JTGYK'nın 5. maddesindedir. Eski düzenlemede Jandarma teşkilatının kuruluş ve kadrolarıyla görev yerlerinin tespitinde asli yetkinin Genelkurmay Başkanlığına ait olduğu ve TSK esaslarına göre düzenleneceği ifade edilmekteydi. Yeni düzenlemeyle, Jandarma Genel Komutanlığının kuruluş ve kadrolarıyla konuş yerlerinin belirlenmesinde asli yetkilinin İçişleri Bakanlığı olduğu, istisnai olarak seferberlik ve savaş gibi olağan üstü durumlarda Kuvvet Komutanlıkları emrine girecek Jandarma birliklerinin kuruluş ve kadrolarıyla konuş yerlerinin Genelkurmay Başkanlığının görüşü alınmak suretiyle yine İçişleri Bakanlığı tarafından tespit edileceği belirlenmiştir.

\subsection{Görevler}

668 sayılı KHK ile Jandarma teşkilatında yapılan başka bir değişiklik Jandarmanın sorumluluk alanında genel olarak görevlerini düzenleyen 2803 Sayılı JTGYK'nın 7. maddesinde yapılmıştır. Eski düzenlemede Jandarma teşkilatının dört temel görev alanının bulunduğu, bu görevlerin sırası ile mülki, adli, askeri ve diğer görevler olduğu ifade edilmişti. Yeni düzenlemede diğer görevler kaldırılmıştır. Bunun yanı sıra Jandarmanın askeri görevleri yeniden tanımlanmış, askeri mevzuat ile Genelkurmay Başkanlığı tarafından Jandarma teşkilatına görev verme usulüne son verilmiş, Jandarmanın askeri görevleri, sadece kanun ve Cumhurbaşkanlığ 1 Kararnamesi ile verilen askeri hizmetlerin ifası ile sinırlandırılarak bu görev alanı tamamen sivil yönetimin kontrolüne bırakılmıştır.

Jandarmanın mülki görevleri genişletilmiş, adli ve askeri görevlerin dışında kalan hususlara ilişkin Jandarmaya verilen görevler, mülki görev alanına başka bir ifadeyle idari kolluk faaliyetleri kapsamına dahil edilmiştir. Yeni düzenlemede üzerinde değişiklik yapılmayan tek görev alanı adlı görevler olmuştur.

Olağan dönemlerdeki bu görevlerin yanı sıra seferberlik ve savaş gibi olağan üstü durumlarda Jandarma birliklerinin Kuvvet Komutanlıklarına katılması, 25/07/2016 tarih ve 668 sayılı KHK ile 2803 Sayılı JTGYK'nın 8. maddesinde yapılan değişiklikle yeniden belirlenmiştir. Eski düzenlemede seferberlik, sıkıyönetim ve savaş durumlarında doğrudan Genelkurmay Başkanlığı kararı ile Jandarma teşkilatının bir bölümü Kuvvet Komutanlıkları emrine girmekteydi. Yeni düzenleme ile Jandarma birlikleri; seferberlik ve savaş hallerinde, Cumhurbaşkanı kararıyla Kuvvet Komutanlıkları emrine girmektedir. Burada dikkat edilmesi gereken iki husus vardır. Birincisi, Sıkıyönetim uygulaması anayasa değişikliği ile yürürlükten kaldırıldığ 1 için buna uygun olarak 15/08/2016 tarih ve 674 sayılı KHK ile yapılan düzenlemeyle 2803 sayılı kanunda yer alan Jandarma birliklerinin kuvvet komutanlıkları emrine girmesini düzenleyen olağanüstü durumlar arasından sıkıyönetim başlığı kaldırılmıştır. İkincisi ve daha önemlisi Jandarma birliklerinin seferberlik ve savaş halinde belirli bir bölümünün Kuvvet Komutanlıklarına katılması, Cumhurbaşkanı kararıyla mümkün hale getirilmiştir.

Bunun dışında yine Genelkurmay Başkanlığının talebi üzerine İçişleri Bakanı, illerde ise garnizon komutanının talebi üzerine Vali onayıyla Jandarma birlikleri kendilerine verilen askeri görevleri yerine getirebilmektedir. Yeni düzenleme ile olağan üstü durumlarda Jandarma birliklerinden istifade edilmesi hususunda asli yetki sivil makamların uhdesinde yer almaktadır. 
2803 Sayılı JTGYK'nın 10. maddesinde Jandarmanın genel görev ve sorumluluk alanı; polis görev sahası dışında, il ve ilçe belediye hudutları haricinde kalan veya polis teşkilatı bulunmayan yerler olarak belirlenmiştir. Ayrıca, belediye sınırları içinde kalmakla birlikte hizmet gerekleri bakımından uygun görülen alanlar, Jandarmanın görev ve sorumluluk alanı olarak tespit edilebilmektedir. 25/07/2016 tarih ve 668 sayılı KHK ile bu hususta yapılan yeni bir düzenleme ile İçişleri Bakanına bir il veya ilçenin tamamını polis ya da jandarma görev ve sorumluluk alanı olarak belirleyebilme yetkisi verilmiştir.

Ayrıca, 15/08/2017 tarih ve 694 sayılı KHK ile bu konuda yapılan ek bir düzenlemeyle, merkezi idarenin taşra teşkilatı olarak kabul edilen il ve ilçelerde jandarma ve polis sorumluluk alanları ilçelerde kaymakam, illerde vali veya görevlendireceği vali yardımcısı başkanlığında oluşturulacak bir komisyon tarafından tespit edilecek olup komisyon kararları İçişleri Bakanı onayı ile yürürlüğe girecektir. Yine bu KHK ile getirilen diğer bir yenilik olarak, Jandarma teşkilatı görevlerini diğer kolluk kuvvetleri ile iş birliği ve koordinasyon içerisinde icra edecektir.

Bu alanda başka bir yenilik olarak, Jandarmanın ilişkileri, çalışma ve iş birliği esaslarını düzenleyen 2803 Sayılı JTGYK'nın 12. maddesinde 25/07/2016 tarih ve 668 sayılı KHK ile yapılan değişiklikle, Bakanlığa bağlı kolluk birimleri olan Emniyet Genel Müdürlügü, Sahil Güvenlik Komutanlığı ve Jandarma Genel Komutanlığı arasında geçici olarak personel görevlendirmesi İçişleri Bakanı onayı ile yapılabilmekte olup Bakan bu yetkisini il valilerine devredebilmektedir. Yine, bu kolluk kuvvetleri arasında silahmühimmat, taşınır-taşınmaz devri veya geçici tahsisi yine İçişleri Bakanı onayı ile yapılabilmektedir.

Yukarıda belirtilen düzenlemelerden yola çıkarak, kolluk hizmetlerinde etkinlik sağlamak ve personel, teçhizat vb. konularda kaynak tasarrufu sağlamak amacıyla İçişleri Bakanına, Bakanlığa bağlı bütün kolluk teşkilatlarını tek bir teşkilat gibi yönetme imkanı verildiği anlaşılmaktadır.

\subsection{Personel Kaynağı ve Özlük Hakları}

25/07/2016 tarih ve 668 sayılı KHK ile Jandarma teşkilatında yapılan diğer bir değişiklik, Jandarmanın personel ve kaynaklarını düzenleyen 2803 Sayılı JTGYK'nın 13. maddesi ve 657 sayılı Devlet Memurları Kanunu'nun 36. maddesinde yapılmıştır. Eski düzenlemeye göre, Jandarma teşkilatında görev yapan subay ve astsubaylar, 926 sayılı Türk Silahlı Kuvvetleri Personel Kanunu'na, Uzman Jandarmalar ise 635 sayılı Uzman Jandarma Kanunu'na tabi olup genel itibariyle rütbeli personel, 657 Sayılı Devlet Memurları Kanunu kapsamı dışında tutulmuştur. 668 sayılı KHK ile, 657 sayılı Devlet Memurları Kanunu'na tabi kurumlarda görevli memurların hizmet sınıflarını düzenleyen 36. Maddesine "Jandarma Hizmetleri Sınıfi" eklenmiş ve bu sınıfın Jandarma Genel Komutanlığı kadrolarında bulunan subay, astsubay ve uzman jandarmaları kapsadığı hüküm altına alınmıştır.

Yeni düzenlemeyle Jandarma Hizmetleri Sınıfı personelinin her türlü özlük işlerinde 657 sayılı Devlet Memurları Kanunu'nun uygulanacağına vurgu yapılmıştır. Ancak, rütbeli personelin eski düzenlemeden kaynaklı kazanılmış haklarından istifade edebilmeleri amacıyla 18/10/2018 tarih ve 7148 sayılı kanunla 13. maddeye yapılan eklemeyle personelin nasıp, terfi, aylık ve diğer mali ve sosyal haklarında statü ve rütbelerine göre 926 sayılı Türk Silahlı Kuvvetleri Personel Kanunu, 4678 sayılı Türk Silahlı Kuvvetlerinde İstihdam Edilecek Sözleşmeli Subay ve Astsubaylar Hakkında Kanun, 3466 sayılı Uzman Jandarma Kanunu ve 3269 sayılı Uzman Erbaş Kanunu'nun uygulanmaya devam edeceği hüküm altına alınmıştır.

Ayrıca, Jandarma teşkilatının yeni rütbeli personel ihtiyacını karşılamak amacıyla 25/07/2016 tarih ve 669 sayılı KHK ile yükseköğretim kurumu seviyesinde İçişleri Bakanlığına bağlı Jandarma ve Sahil Güvenlik Akademisi (JSGA) kurulmuş, böylece teşkilata insan kaynağı yetiştirme açısından Jandarma teşkilatı akademik bir kuruma sahip olmuştur (Avaner, Tek ve Özgür, 2019: 5).

\subsection{Atama}

3 Sayılı Cumhurbaşkanlığı Kararnamesi ve 703 sayılı KHK ile Jandarma teşkilatında personel atamalarının usul ve esasları yeniden belirlenmiştir. Üst Kademe Kamu Yöneticileri ile Kamu Kurum ve Kuruluşlarında Atama Usullerini düzenleyen 3 Sayılı Cumhurbaşkanlığ 1 Kararnamesinin 11. maddesine göre, Jandarma Genel Komutanı'nın generaller arasından Cumhurbaşkanı kararı ile, Jandarma Genel Komutanı Yardımcıları, Bölge Jandarma Komutanları ve İl Jandarma Komutanlarının ise Cumhurbaşkanı onayı ile atandığı görülmektedir. 703 sayılı KHK ile 2803 sayılı JTGYK'nın 14. maddesinde yapılan 
değişikliğe göre yukarıda belirtilenler dışında kalan Jandarma personelinin atamaları İçişleri Bakanı tarafından yapılmakta olup İçişleri Bakanı kararı ile nokta ataması yapılmayan subay, astsubay ve uzman jandarmalar doğrudan valilik emrine atanmakta, bunların il içinde görev yerlerinin tespiti ve yer değişikliği vali tarafından yapılmaktadır. Yeni düzenlemeyle, Jandarma personelinin atamalarında askeri makamların etkisi ortadan kalkmış, atama süreçlerinin her aşamasında yetki sivil makamlara geçmiştir.

\subsection{Disiplin ve Soruşturma İşlemleri}

668 sayılı KHK ile 2803 sayılı JTGYK'nın 15. maddesinde yapılan değişiklikle Jandarma personeli hakkında yürütülecek disiplin ve soruşturma işlemlerinin yöntemi yeniden belirlenmiştir. Jandarma personelinin disiplin işleri özel kanun hükümlerine göre yürütülecek olup mülki görevlerden doğan suçlarda, 4483 sayılı Memurlar ve Diğer Kamu Görevlilerinin Yargılanması Hakkında Kanun, adli görevlerden doğan suçlarda 5271 sayılı Ceza Muhakemesi Kanunu uygulanacak, kişisel suç durumunda ise genel hükümlere göre işlem yapılacaktır.

Yukarıda belirtildiği üzere Jandarma Genel Komutanlığının yanı sıra diğer genel kolluk kuruluşları olan Emniyet Genel Müdürlüğü ve Sahil Güvenlik Komutanlığı personeline ilişkin disiplin cezaları, disiplin amirleri ve kurulları, disiplin soruşturma usulleri vb. hususlar OHAL döneminde ilk olarak 682 sayılı KHK ile düzenlenmiş akabinde 7068 sayılı Genel Kolluk Disiplin Hükümleri Hakkında Kanun Hükmünde Kararnamenin Kabul Edilmesine Dair Kanunla genel kolluğa ilişkin disiplin işlemleri ayrıntılı olarak düzenlenmiştir.

Ayrıca, 694 sayılı KHK ile bu düzenlemelere ek olarak; işlediği suç nedeniyle bir yıl ve üzeri süreyle hapis cezasına mahkûm olan Jandarma personelinin teşkilatla ilişiğinin İçişleri Bakanı onayı ile kesilebileceği hüküm altına alınmıştır. Yeni düzenlemeler vasıtasıyla, Jandarma personelinin disiplin işlemlerinin askeri usul ve esasların dışına çıkarıldığı, bu alanın ayrı bir kanunla düzenlenerek sivil makamların yetkisine verildiği görülmektedir.

\section{8. İkmal Esasları}

668 sayılı KHK ile yapılan diğer bir değiş̧iklik Jandarmanın ikmal esaslarını düzenleyen 2803 Sayılı JTGYK'nın 19. maddesinde olmuştur. Eski düzenlemede Jandarma teşkilatının ikmal hizmetleriyle, faaliyetlerine ilişkin her türlü ihtiyaçları Türk Silahlı Kuvvetleri standartlarına uygun olarak kendi bütçesinden karşılanırken yeni düzenlemeye göre İçişleri Bakanlığınca belirlenecek standartlara uygun olarak kendi bütçesinden karşılanacaktır. Eski düzenlemeye göre silah ve mühimmat ihtiyacı Milli Savunma Bakanlığı tarafından temin edilirken yeni düzenlemede Jandarma teşkilatının her türlü silahmühimmat ihtiyacının İçişleri Bakanlığı tarafindan doğrudan Savunma Sanayii Müsteşarlığına teklif edilebileceğine yer verilmiştir.

Böylece Jandarma teşkilatının ikmal hizmetleriyle faaliyetlerinin askeri standartlara göre yerine getirilmesi uygulamasına son verilmiş olup, İçişleri Bakanlığı tarafindan belirlenecek standartlara uygun olarak yerine getirilecek ve silah-mühimmat vb. ihtiyaçları İçişleri Bakanlığı tarafından karşılanacaktır.

\section{SONUÇ}

İnsanların hayatlarını idame ettirebilmesi ve temel gereksinimlerini karşılama zorunluluğu, diğer insanlarla iletişim içinde olması ve toplum içinde yaşamasını gerekli kılmıştır. Toplum içinde yaşam da hem bireylerin dış tehditlere karşı korunmasını hem de toplu hayatın bir düzen içerisinde sistematik olarak devamını gerektirmektedir. İnsanın temel ihtiyaçları içinde yemek-içmek, nefes almak vb. fiziksel ihtiyaçlarından sonra ikincil temel ihtiyaç olarak sayılan güvenlik ihtiyacı devletler tarafından kamu hizmeti olarak sunulmaktadır. İnsanların kendini güvende hissetmediği, asayişin sağlanamadığı, suç ve suçluyla tam olarak mücadele edilemediği bir ortamda diğer kamu hizmetlerinden söz edilmesi güçtür. Devletin, yerine getirdiği kolluk hizmetine ilişkin bu alanda uzmanlaşmış müstakil bir örgütlenmeye sahip olması kaçınılmazdır.

Türkiye'de 1983 yılında yürürlüğe giren 2803 Sayılı kanunda Jandarma teşkilatı askeri hiyerarşi içerisinde faaliyet gösteren askeri bir kolluk kuvveti olarak teşkil edilmiştir. Bu Kanun'da Jandarma teşkilatı her ne kadar emniyet ve asayiş hizmetlerinin yerine getirilmesinde İçişleri Bakanlığına bağlı olarak görülse de bir bütün olarak ele alındığında, Jandarmanın TSK'ya hiyerarşik bir bağ ile bağlı olup onun bir parçası olduğuna vurgu yapılması, hemen hemen her konuda asli yetkinin askeri makamlara ait olması, 
hizmet standartlarının askeri usullere göre tespit edilip görevlerin askeri yöntemlere göre yerine getirilmesi nedeniyle Jandarmanın askeri yönünün kolluk yönünden daha baskındı.

Jandarma teşkilatı, 182 yıllık tarihi ve tecrübesi ile asayiş ve güvenlik hizmeti başta olmak üzere savaş, doğal afet gibi durumlarda üstlendiği görevler ile en zorlu arazi şartlarında her türlü kamu hizmetinin yerine getirilmesine sağladığı katkı ile taşrada devletin varlığını vatandaşa hissettiren ilk kurumdur. Tüm il ve ilçelerde hatta hizmet gerekleri bakımından ihtiyaç duyulan köy, mezra vb. yerleşim yerlerinde konuşlanmış olan Jandarma teşkilatı, Türkiye'de en yaygın taşra teşkilatlanmasına sahip kurum olma özelliğinin yanı sıra kolluk kuruluşları içerisinde en geniş sorumluluk alanına sahip olan kamu idaresidir. Özellikle kırsal alanda yaşayan vatandaşlar açısından Jandarma, en yakın kamu idaresidir. Türkiye'de askeri yönetimler tarafından gerçekleştirilen askeri darbelerde taşrada darbeyi uygulama görevi Jandarma'ya düşmekteydi. 15 Temmuz darbe girişiminde de bu durum uygulanmaya çalışılmış ancak birçok il ve ilçede, TSK içine sızmış FETÖ mensuplarının önlenmesinde jandarmanın önemli rolü olmuştur.

Darbe girişiminden sonra Jandarma teşkilatının TSK ile olan hiyerarşik bağının kesilmesi ve İçişleri Bakanlığı'na bağlanması sonrasında, asli yetkinin sivil makamlara devredildiği, Jandarmanın askeri kolluk vasfına son verilerek genel kolluk kuvveti sıfatıyla İçişleri Bakanlığı'nın bağlı bir kuruluş haline geldiği, askeri görevlerinin ise sadece seferberlik ve savaş durumunda kanun ve Cumhurbaşkanlığı Kararnamesi ile verilen askeri hizmetlerin ifası ile sınırlandırıldı ğı görülmektedir.

\section{KAYNAKÇA}

Açıkmeşe, İ. (1993). Cumhuriyetin 70. Yılında Jandarma Genel Komutanlığı. Türk İdare Dergisi. Sayı 401, ss.311-330.

Akman, N. (1991). Yönetimde İ̧̧ Güvenlik ve Jandarma. Ankara: Genel Kurmay Basımevi.

Aktürk, İ., Ersan, K., Özbek, M., Savlık, N. ve Sarıer, O., (2004). Jandarma Meslek, Cilt 1, Ankara: Jandarma Basımevi.

Akyılmaz, B., Sezginer, M., Kaya, C., (2016). Türk İdare Hukuku, 7. Baskı, Ankara: Seçkin Yayınevi.

Avaner, T., Erciyes, E. (2019). "Yönetim ve Güvenlik", Yönetimlere Disiplinler Arası Yaklaşım (Editör: M. Akif Özer), Ankara: Gazi Kitabevi, ss.115-134.

Avaner, T., Şencan, M. (2019). “Türkiye'de İç Güvenlik Sistemi ve Geleceği Üzerine Değerlendirmeler”, Uluslararas1 Güvenlik Kongresi Bildiri Kitabı, ISBN:978-605-035-007-4. ss. 613-634.

Avaner, T. Ak, T. Özgür, E. (2019). “Günümüzün İç Güvenlik ve Kamu Yönetimi Yaklaşımı Bağlamında Örnek Bir Jandarma Subay Akademik Eğitimi ve Kariyer Modeli”, ASSAM Uluslararası Hakemli Dergi, 13. Uluslararası Kamu Yönetimi Sempozyumu Bildirileri Özel Sayısı, ss. 1-19.

Çermeli, A. Ve Atabey, H. (2002). Jandarma Genel Komutanlığı Tarihi, Asayiş ve Kolluk Tarihi İçerisinde Türk Jandarma Teşkilatı, Cilt 1, Ankara: Kozan Ofset.

Doğan, F. (2010). Polis ve Jandarma Teşkilatları Açısından İç Güvenlik Yönetimi, Sorunları ve Değişimi. (Yayınlanmamış Yüksek Lisans Tezi). Ankara Üniversitesi Sosyal Bilimler Enstitüsü.

Efe, İ. (2016). 30 Ekim 1918' den Ocak 1921'e Teşkilat, Tensîkât ve İcraatlarıyla Türk Jandarmas1. Çankırı Karatekin Üniversitesi Sosyal Bilimler Enstitüsü Dergisi. 7(1): 583-602.

Gözler, K. Ve Kaplan, G. (2011). Kisa İdare Hukuku. Bursa: Ekin Kitabevi.

Gözler, K. Ve Kaplan, G. (2018). İdare Hukuku. 24. Bask1, Bursa: Ekin Kitabevi.

Güner, S. (2011). Kolluğun Zor ve Silah Kullanması, (Yayınlanmamış Yüksek Lisans Tezi). İstanbul Kültür Üniversitesi Sosyal Bilimler Enstitüsü.

İleri, F. (2004). Genel İdari Kolluk ve Mülki İdare Amirlerinin Genel İdari Kolluk Yetkileri. (Yayınlanmamış Yüksek Lisans Tezi). Konya: Selçuk Üniversitesi Sosyal Bilimler Enstitüsü.

JOK, (2004). Jandarma Taktiği I, Ankara: Öğretim Başkanlığı Yayınları. 
Kahraman, M. (2000). Türk İdari Teşkilatında Jandarma, Yayımlanmamış Yüksek Lisans Tezi, Selçuk Üniversitesi Sosyal Bilimler Enstitüsü, Konya.

Korkusuz, R. (1998). Uluslararası Belgelerde ve Türk Anayasasında Temel Hak ve Özgürlükler, İstanbul: Özrenk Matbaacılık.

Özbek, N. (2009). İkinci Meşrutiyeti Hazırlayan Koşullar: Rumeli’ de Vergi Tahsilatı ve Jandarma. Toplumsal Tarih Dergisi, Say1 183, ss.46-50.

3 Sayılı Üst Kademe Kamu Yöneticileri ile Kamu Kurum ve Kuruluşlarında Atama Usullerine Dair Cumhurbaşkanlığ1 Kararnamesi, https://www.resmigazete.gov.tr/eskiler/2018/07/20180710-3.pdf, (01.12.2019).

657 Sayılı Devlet Memurları Kanunu, https://www.mevzuat.gov.tr/MevzuatMetin/1.5.657.pdf, (02.12.2019).

668 Sayılı Olağanüstü Hal Kapsamında Alınması Gereken Tedbirler ile Bazı Kamu Kurum ve Kuruluşlara Dair Düzenleme Yapılması Hakkında Kanun Hükmünde Kararname, http://www.resmigazete.gov.tr/eskiler/2016/07/20160727M2.htm, (03.12.2019).

669 Sayılı Olağanüstü Hal Kapsamında Alınması Gereken Tedbirler ile Bazı Kamu Kurum ve Kuruluşlara Dair Düzenleme Yapılması Hakkında Kanun Hükmünde Kararname, http://www.resmigazete.gov.tr/eskiler/2016/07/20160731-5.htm, (04.12.2019).

674 Sayılı Olağanüstü Hal Kapsamında Bazı Düzenlemeler Yapılması Hakkında Kanun Hükmünde Kararname, https://www.resmigazete.gov.tr/eskiler/2016/09/20160901M2-2.htm, (05.12.2019).

694 Sayılı Olağanüstü Hal Kapsamında Alınması Gereken Tedbirler ile Bazı Kamu Kurum ve Kuruluşlara Dair Düzenleme Yapılması Hakkında Kanun Hükmünde Kararname, http://www.resmigazete.gov.tr/eskiler/2017/08/20170825-13.pdf, (06.12.2019).

703 Sayılı Olağanüstü Hal Kapsamında Alınması Gereken Tedbirler ile Bazı Kamu Kurum ve Kuruluşlara Dair Düzenleme Yapılması Hakkında Kanun Hükmünde Kararname, http://www.resmigazete.gov.tr/eskiler/2018/07/20180709M3.pdf, (07.12.2019).

2803 Sayılı Jandarma Teşkilat, Görev ve Yetkileri Kanunu, https://www.mevzuat.gov.tr/MevzuatMetin/1.5.2803.pdf, (08.12.2019).

3201 Sayılı Emniyet Teşkilat Kanunu, https://www.mevzuat.gov.tr/MevzuatMetin/1.3.3201.pdf, (9.12.2019). 